\title{
Virtual Labs of Analog Oscillator
}

\author{
http://dx.doi.org/10.3991/ijoe.v12i08.5911 \\ Syifaul Fuada, Amy Hamidah Salman \\ Institut Teknologi Bandung (ITB), Indonesia
}

\begin{abstract}
- this paper discusses the functional system of a learning media product development; the design and implementation of a virtual lab with analog oscillator comprising 4 (four) practical topics of digital oscillator, namely (1) Wien Bridge oscillator, (2) Colpitts oscillator, (3) Hartley oscillator and (4) Astable Multivibrator. This Virtual Laboratory was built using Adobe Flash CS6 action script 3.0. It comprises several parts, they are initial page (flash scren), main page or home page, practical page and a page about the developer. This media is accessed offline on a computer standalone based with the extension of .exe or .swf which is constructed by 24 frames per second (fps). This media can be operated by changing the Resistor $(R)$, Inductor (L) and Capacitor (C) components and being continued to the plug and play from the RLC to the tool kit or trainer kit, while the output can be seen in the measuring devices; the frequecy counter and oscilloscope. The second product is a digital jobsheet as a supplementary for the practical which contains prequisites for conducting the practical, introduction, anatomic information of the virtual lab, directions for using e-jobsheet and the virtual lab, as well as the practical procedures and test items for evaluation.
\end{abstract}

Index Terms-Virtual lab, analog oscillator

\section{INTRODUCTION}

Oscillator/frequency generator is a part of the electronic system that serves to generate frequency in its form of sinusoid, square, sawtooth or triangle. Oscillator material is usually delivered in courses at various Indonesia's universities having electronics department; both in science and education. It is commonly found in the course of industrial instrumentation, op-amp, analog electronics, telecommunication electronics, signals and systems, or it may be covered in other relevant subjects.

For certain university laboratories apply the rule "every costly laboratory device and those which are limited in number, are not allowed to be borrowed as to be taken home by students". Consequently, the students cannot complete any practical outside the lab, for the measuring devices to verify their experiment are not to be out of the lab. This also applies to the case of the practices (especially the signal generator/oscillator) in which it utilizes a high price measuring instrument, like oscilloscope and frequency counter.

In order to assist students in learning, it is crucial to provide them with a learning made comprising oscillator materials that is integrated with digital practices. To this, one proposed solution is the use of a computer program termed "the virtual lab" which means an electronic learning media comprising texts, images, audio, animation and simulator that can simulate practicals appropriately as if users are doing them on their own.
A number of benefits are offered in a virtual computer lab program, namely; Improving learning effectiveness, a virtual lab can help students complete a practical in case they could not finish it in the real laboratory, which then it is expected to help achieve the specific competence; Improving the efficiency of teaching media, virtual lab is appropriate to substitute a practical when it requires very costly instrument or if it uses the only one instrument from the lab or should the instruments provided in the lab are limited in number to cover the new wave of students in a college; Improving the safety working, virtual lab aptly applied replace any practical tool which is prone to workplace accidents [1], for example, high probability of high electric shock.

According to the characteristics proposed by GUI, Virtual labs are divided into two, they are 2D and 3D based. This type of learning media has been widely implemented in a number of electronic engineering education and training, such as the topic of basic electronic [2], digital electronic [3], robotic [4] or mechatronic [5], Control system [6], Electric machines [7], Power Electronics [8], energy generation [9], computer programming [10] and other relevant scopes. Besides the practical material, this learning media also includes some other facilities, to name a few online meetings, online test and so on, group discussions.

This paper serves the author to report the product development of virtual lab taking the topic of analog oscillator which is operated on the PC and e-jobsheet as a practical guide. The material for oscillator consists of Wien Bridge oscillator, Hartley oscillator, Colpitts oscillator and Astable Multivibrator. It was built using Adobe Flash due to several advantages, namely, (1) as a multimedia builder devices with fine interactivity and motion animation; (2) the programming language uses simple yet powerful actionscript, particularly when using preprepared componentslike drop-down menus, text boxes, and buttons; (3) Flash can be used to implement virtual experiments with the high quality of the graphical user interface/GUI [11]. The already developed virtual lab was limited for practical related activities; while preface for preconditions, objectives and tutorials, complete material of each oscillator development, and evaluation are provided in a separate jobsheet.

The development of this product can later be used as a supplement for teaching materials that are flexible and practical for learning basic analog oscillator covering $\mathrm{RC}$, LC and Relaxation.

\section{Traditional LAB Vs MODERn LAB}

The word 'traditional' here does not refer to using outfashioned technology devices, but more to the conventional implementations or practices. This traditional laboratory requires instruments, circuits, and 
authentic measuring instruments, like: probe cable, $\mathrm{RC}$ or LC series circuit, and oscilloscope. Because of these particular requirements, generally people cannot conduct any experiment. Conducting experiment via interactive simulations can offer opportunities for students and other people who have limited access to the instruments like of those in an actual laboratory. Virtual laboratory is designed to ease such experiment conducts that the students can function common devices in their surroundings to try out the practical. Simply by using a regular computer and the Internet connection, for instance, succeeds the delivery of learning materials to the students as well as the practical activities. Using this virtual lab the students may not have direct contact with the learning resources such as the labs and instructors in order to understand the subject matter. In other words, the virtual laboratory is a system designed to support the practical system carried out traditionally.

\section{VIRTUAL LAB DESIGN}

The virtual lab we have developed is based on the combination of knowledge elements with pleasure in doing practical and a reconstruction or simulation of the real state of the characteristics of output oscillator signal to be able to provide insight to students concerning the basic concepts as well as to provide skills in designing, assembling and testing the oscillator circuit.

By now, we have developed the oscillator trainer board product [12-13] of LC and RC types, and it has gone through expert validation [14]. There are two types of board, namely oscillator board and RLC board. Meanwhile, the virtual lab platform used in this study is based on previous relevant works.

\section{A. Story Board}

The developed story board of the virtual lab is shown in Figure 2 and Figure 3 for the flowchart. The interface to be displayed on the desktop laptop (computer standalone) is presented in a 2-Dimension design.

In the window for practical, toolkit, oscilloscope display and the frequency generator have been provided thus the practitioner can operate this application by the 'plug and play' from the 'tool kit' to Resistor/Capacitor/Inductor module.

The students see the magnitude of the frequency and time generated by the provided measuring instrument. Splicing the $\mathrm{R} / \mathrm{L} / \mathrm{C}$ module to the tool kit is determined (depending on the measurement table in jobsheet). Thus the students may not try and err the plug and play activity, for the practicum should be done based on the theory correctly. After doing a practical, the student is required to record the data and analyze the results of practical, and then write the lab report. Finally, the student is required to do a self-evaluation by answering the questions provided in the e-jobsheet.

\section{B. Properties}

The program used to design 2D was Microsoft Visio 2007, while the Graph Editor administered CorelDraw Xsuite and Photoshop CS6. Animation developer and programming were completed in Adobe Flash CS6. Meanwhile, all these were created in a computer using OS Windows 7 licensed 64bit. There are properties required for this matter:

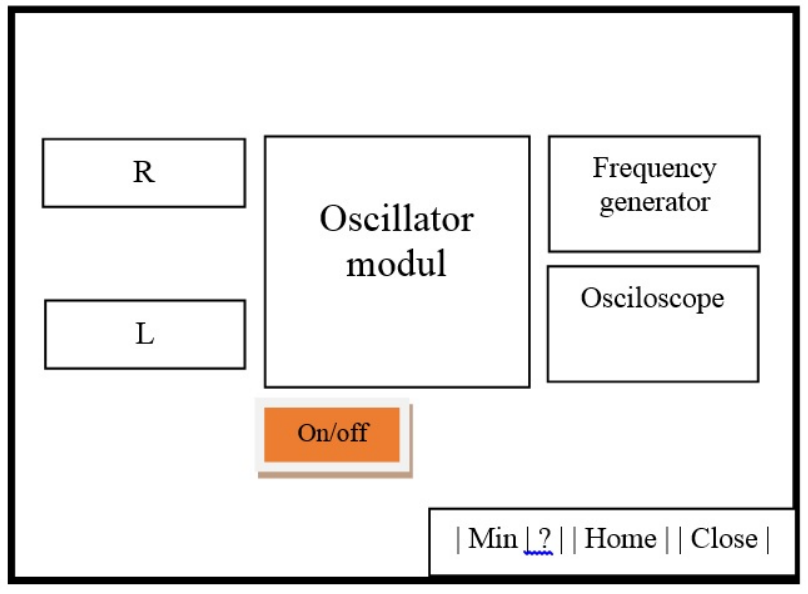

Figure 1. Analog virtual lab Story board

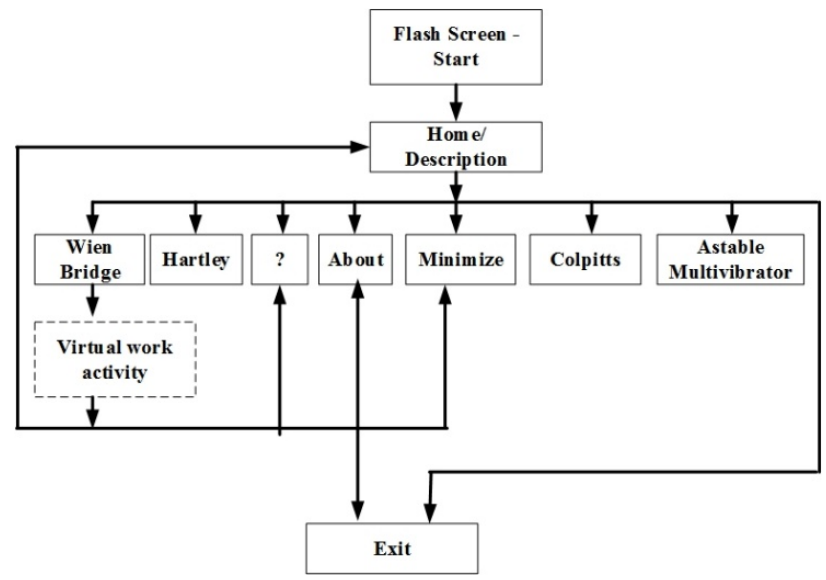

Figure 2. Analog virtual lab flowchart

- Background: workshop table

- Measuring devices: oscilloscope, frequency counter with two modes (frequency and time)

- Practical instruments: virtual based jumper and power supply operated by on and off (without jumpering)

- Practical aids: Oscilator Wien Bridge, Oscilator Hartley, Oscilator Colpitts, Astable Multivibrator, Modul Resistor $1 \mathrm{~K} \Omega, 10 \mathrm{~K} \Omega, 2 \mathrm{~K} \Omega, 20 \mathrm{~K} \Omega, 3 \mathrm{~K} \Omega$ \& $30 \mathrm{~K} \Omega$, Modul Kapasitor $10 \mathrm{nF}, 100 \mathrm{nF}, 1 \mathrm{uF}, 10 \mathrm{uF}$, $100 \mathrm{uF} \& 100 \mathrm{uF}$, Modul Induktor $10 \mathrm{H} \& 5 \mathrm{H}$

The audio usage in this virtual lab exists in every activity of plug and play, namely: voice activity of connecting between properties, on-off sound in power supply and switching from frequency to time mode or vice versa in a frequency counter, button sound for choosing practical and the close button and Yes/no button as well. None of the sound is created; they are available in Google under the condition without watermark.

\section{Distribution of virtual lab}

This virtual lab is an offline application, therefore the distribution can be done by uploading to the Google Drive platform, Dropbox, Moodle, etc., so that students can easily download and do lab work independently wherever they are, be they in the classroom or outside the classroom. The distribution can also be done through data transferring using a Compact Disk or Flash Disk. 


\section{E-JOBSHEET DESIGN}

The existence of digital jobsheet or e-jobsheet is expected to facilitate the learning activities, so that the practical process can run smooth and that it allows the students to carry out practical outside electronics laboratories.

The digital Jobsheet or e-jobsheet comprises several contents: (1) Prerequisites containing what knowledge the students should have in prior to carry out a virtual lab oscillator; (2) Introduction consisting of manuals for using the e-jobsheet both for teachers/ lecturers and students; (3) Directions for use is the lab technical instructions of how to execute analog oscillator from the virtual laboratory. The information delivered is about the anatmy of virtual laboratory and oscillator tool kit; (4) Table of contents; (5) Practical sheet comprising the learning objectives, explanation of the theory of each oscillator, test table, analysis and conclusions; (6) Exercises, its aim is to investigate the students' ability in understanding the material of each oscillator and (7) References, which is a list of other learning resources such as books or websites that are recommended as reference material for further reading.

Texts at the e-jobsheet is written by 'Times New Roman' font with $12 \mathrm{pt}$, because there is standard text and size and it always use for developing handbook, tutorial, worksheets, etc. Space between paragraphs is $1,5 \mathrm{pt}$ and after-before with 0 pt.

To make it more appealing, the e-jobsheet cover is made using Adobe Photoshop. The color used in the design is blue, which is the dominant color used in the virtual lab. Both texts and images on the cover are designed clear to suit the subjects presented and using simple words.

Like the virtual lab, e-jobsheet is also accessed offline and compatible with PCs or mobile phones. This way, the distribution is recommended to be in one package with the virtual lab application.

\section{RESUlT AND ANALYSIS}

The virtual lab is a file with .swf extension or .exe file with a capacity of $8,41 \mathrm{MB} 24 \mathrm{fps}$, compatible with PCs or laptops that have installed Flash Player.

\section{A. Virtual lab content}

Virtual Laboratory consists of initial display of flash screen animation page, home page, practical pages, and pages about the developer. The making of this Virtual Laboratory refers to the story board presented in Figures 1 and 2. The display of flash screen animation page always appears initially at everytime a user opens the application. This initial page contains the copyright for the developer, sponsors, years of funding, and logos of affiliate sponsors and the the author's institution. Then, appearing the "enter" button, the practitioner must press this "enter" button to link him to the oscillator practical options.

The home page as shown in Fig. 5 shows the profile of the developer and practical options, consisting of oscillator: (1) Wien Bridge, (2) Colpitts, (3) Hartley and (4) Astable Multivibrator, if either of the menu is clicked, the display will refers straight to the worksheet for oscillator practices.

Description contains an overview of the oscillator virtual laboratory along with brief directions for use. The page about the developer will appear only if the "profile"

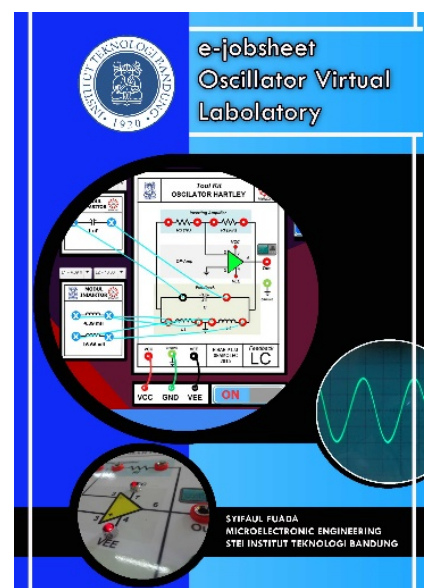

(a)

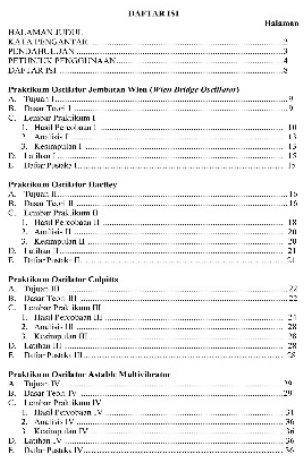

(b)
Figure 3. The e-jobsheet: (a) Cover; (b) table of contents

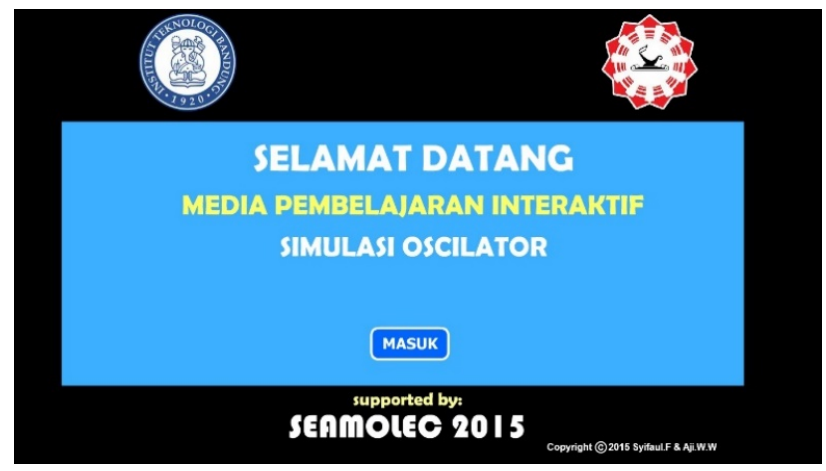

Figure 4. Display flash screen

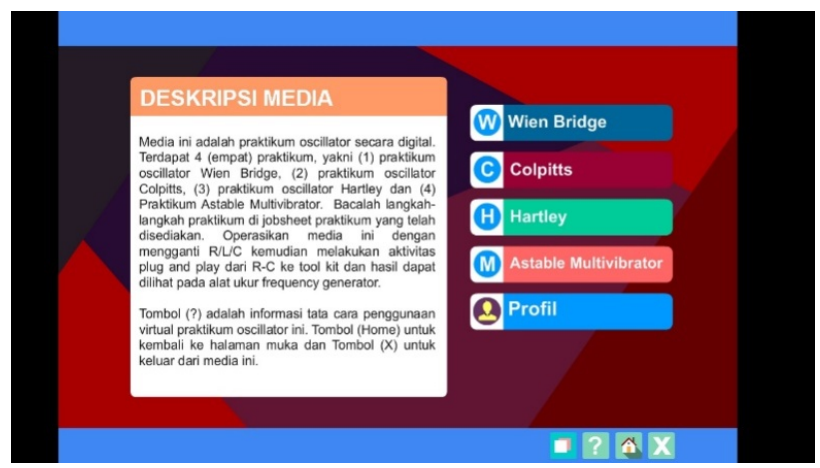

Figure 5. Main page (Home) display

is clicked, in which the page will display the developer team.

Help display as shown in Fig. 6 is linked from the button in a question mark (?). It contains the directions for using virtual laboratory. When the button symbolized with "X" is clicked, a question will come up along with the answers "yes" and "no". If the "yes" button is clicked, the help display is closed. The default display of virtual lab is full screen, yet the user can choose to select the minimize button to adjust the screen size.

Figure 7 is a workbench of Wien Bridge oscillator. Oscillator module has been provided directly on the workbench, so the user can simply select $\mathrm{R} / \mathrm{C}$ in the menu " $\mathrm{R}$ Module" and "C Module". L module is not included in the display due to the fact that Wien Bridge oscillator does not use the "L". Resistor module contains: $1 \mathrm{~K} \Omega, 10 \mathrm{~K} \Omega$, $2 \mathrm{~K} \Omega \& 20 \mathrm{~K} \Omega, 30 \mathrm{~K} \Omega$ and $3 \mathrm{~K} \Omega$ and Capacitor Modules 


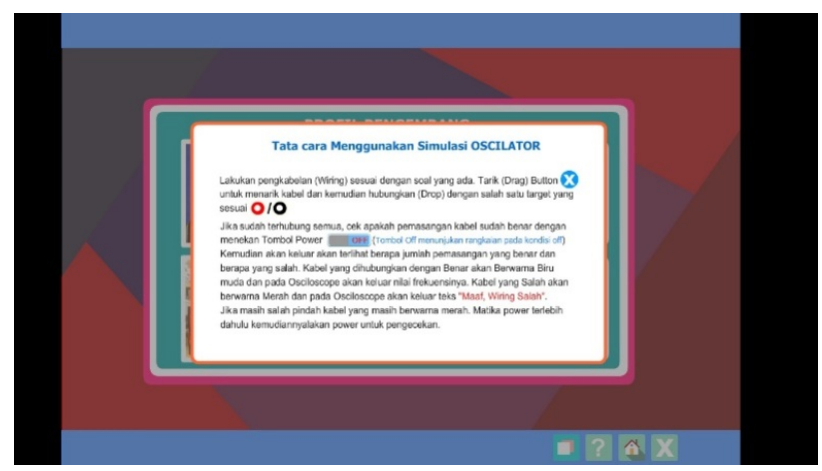

Figure 6. Help display

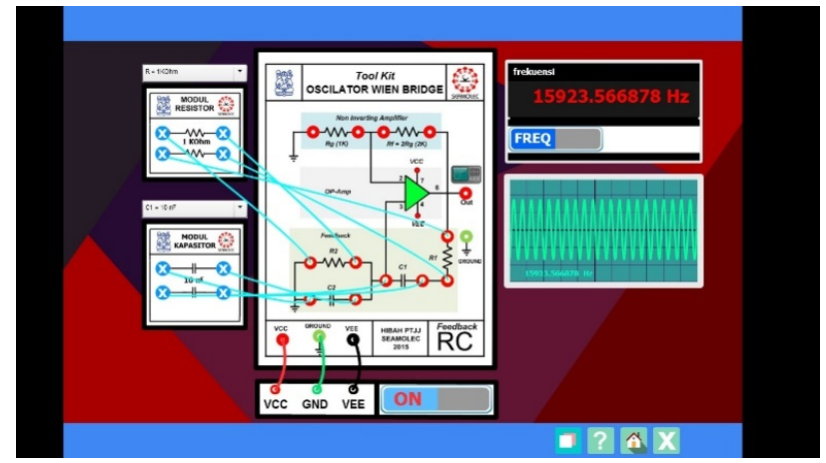

Figure 7. Virtual worklab display of Wien Bridge oscillator

contain, $10 \mathrm{nF}$ and $100 \mathrm{nF}$. Like the Wien Bridege, the Astable Multivibrator is only supplied with the RC module with polarity in C. Resistor module contains $1 \mathrm{~K}, 10 \mathrm{~K}$, $2 \mathrm{~K}, 20 \mathrm{~K}, 3 \mathrm{~K}$, and $30 \mathrm{~K}$. While the Capacitor Module contains $10 \mathrm{nF}, 100 \mathrm{nF}, 1 \mu \mathrm{F}$ and $10 \mu \mathrm{F}$

While in the lab of Colpitts and Hartley, $\mathrm{R}$ module is not included in the display because the oscillator uses L-C with the inductor component of $16,66 \mathrm{mH}$ and $4,39 \mathrm{mH}$ and Component $\mathrm{C}$ : $1 \mathrm{nF}$ and $10 \mathrm{nF}, \mathrm{C} 1 \mathrm{uF}$ and $\mathrm{C} 10 \mathrm{uF}$.

Once $\mathrm{R} / \mathrm{L} / \mathrm{C}$ displayed on the module is selected, the user does the plug and play by pressing the $\mathrm{ON}$ button and sees its output frequency by the measuring device, which is frequency counter and oscilloscope.

\section{B. Descision Requirement}

Based on the characteristics reality of each type oscillator, the virtual lab ought to be capable in performing conditions according to their actual situations. Here are several decisions implemented in programming using the action script 3.0.

1. The indicator light is on and off (OP-AMP color light green blinking) when the power supply is 'ON' and 'OFF' respectively, (OP-AMP color is back to default, i.e., yellow),

2. The value displayed is based on computed calculations of mathematical equations of each oscillator (equation 1 until 4) with a default value of $\pi$ (Phi) $=3.14$ and The following is a mathematical equation of each oscillator,

$$
\begin{aligned}
& f=\frac{1}{2 \pi R C} \quad \text { [Wien Bridge] } \\
& f=1 /(2.1976 \mathrm{RC}) \quad \text { [Astable multivibrator](2) }
\end{aligned}
$$

$$
\begin{gathered}
f=\frac{1}{2 \pi \sqrt{C L_{T}}} \text { [Hartley] } \\
\text { With } \mathrm{L}_{\mathrm{T}}=\mathrm{L} 1+\mathrm{L} 2 \\
f=\frac{1}{2 \pi \sqrt{L C_{T}}} \quad \text { [Colpitts] } \\
\text { With } \mathrm{C}_{\mathrm{T}}=\frac{\mathrm{C} 1 \times \mathrm{C} 2}{\mathrm{C} 1+\mathrm{C} 2}
\end{gathered}
$$

3. There are three decisions in frequency counter, that: (1) an initial default frequency counter is zero, (2) should the circuit network be not connected appropriately or spliced wrongly or mistaken in polarity of the electrolytic, the frequency counter will show "Sorry incorrect circuit network". (3) If the circuit network is properly connected and is turned $\mathrm{ON}$, the execution result will be displayed in numeric, which can be seen from frequency and time mode.

4. The time mode is second (vs), millisecond (ms), dan microsecond (us).

5. There are three decisions on the oscilloscope they are: (1) the initial state is default without signal, (2) should the frequency counter display "sorry wrong circuit network", the oscilloscope will not display the wave and (3) the wave emerges only if the frequency counter displays the results. Oscilloscope displays the sine wave for Wien Bridge oscillator, Hartley, and Colpitts, and square wave particularly for Astable Multivibrator.

6. The resistor/capacitor/inductor is selected by pressing the combobox button; this selection is based on the jobsheet, if the value is clicked, RLC module with the same value as the one selected will be shown. Resistor values have been adjusted to tolerance (we use a tolerance of $5 \%$ ) to fit the real experiment, therefore the function of each resistor is:

Real Value $=$ Resistor Value - (Resistor Val ue x (5/100)).

7. RLC Components are to be connected accordingly, for example: C should be connected with $\mathrm{C}$, when placed on $\mathrm{R}$, (and vice versa), so if switched to $\mathrm{ON} \rightarrow$ "Sorry incorrect circuit network".

8. To connect between kits virtual cables are used, thus the user can operate co connect by dragging and dropping with the intended target.

9. To switch the RLC value and opt other menus cannot be performed when the power supply is turned ON.

10. Cable splicing cannot be performed in parallel (multiple) state, for points targets are in pairs.

11. RLC components should all be in connected state, any of RLC components is not connected when $\mathrm{ON} \rightarrow$ "Sorry incorrect circuit network". 
12. Capacitors colored red and black have the + and poles, thus they cannot be put upside down, should they be inverted $\mathrm{ON} \rightarrow$ "Sorry incorrect circuit network".

13. The prerequisite for Colpitts Oscillator practical is that $\mathrm{C} 1$ should be greater than or equal to $\mathrm{C} 2(\mathrm{C} 1$ $\geq \mathrm{C} 2$ ), for example, $\mathrm{C} 1=100 \mathrm{nF}$, so $\mathrm{C} 2=100 \mathrm{nF}$ or $1 \mathrm{uF}$ or $100 \mathrm{uF}$, and $\mathrm{C} 2$ should not be less than that $(10 \mathrm{nF})$. Should this rule be ignored when ON, the frequency generator will display " 0 " or it will not indicate any frequency rate or time.

14. The prerequisite for Hartley practical is L2 should be be greater than L1 (L2 > L1), for example, L2 $=10 \mathrm{mH}$ then $\mathrm{L} 1$ must be $1 \mathrm{mH}$. Should this rule be ignored when $\mathrm{ON}$, the frequency generator will display "0" or it will not indicate any frequency rate or time

15. Wrongly spliced cable will be colored red as an indicator of failure and of every frequency generator displaying "sorry incorrect circuit network".

\section{Virtual Lab Functional Testing}

This lab virtual product has been tested on a laptop with 64 bit and installed flash player. The test is based on the decisions that have been made, which are testing (1) The polarity of the capacitor with the + and - in the lab Hartley and Colpitts oscillator; (2) Wiring; (3) Frequency and time mode in the frequency counter; (4) Decision applicable in the lab Hartley and Colpitts oscillator. The results are in line with that of the design on the story board (the test results can be seen in supplementary file) and testing and its results on multiple devices can be seen in Table 1 .

Based on the results of tests in Table 1, it is concluded that for the virtual lab to be ready and run well on a computer software system, the following specifications should be completed as minimum requirement: (a) utilizing the operating system Windows 7/XP/Vista. (b) Pentium Core Duo processor or newer version is recommended. (c) RAM memory is $512 \mathrm{MB}, 1 \mathrm{~GB}$ or higher is recommended. (d) Hard Disk capacity of $500 \mathrm{MB}$ or greater and then (e) Flash Player 10.0 version or newer.

\section{Comparation}

In this section, we compare the real oscillator work lab [11] with virtual lab. Table II shows several samples of virtual lab in wiring process, measuring result of oscillator electronic circuit using oscilloscope and frequency counter. It is shown that the measuring result approximates the real lab value (Parameter $\mathrm{R}=20 \mathrm{~K} \mathrm{Ohm}$ and $\mathrm{C}=100 \mathrm{nF}$ ) and the wiring process is more concise than the real worklab. Moreover, the comparation of the Printed Jobsheet dan E-jobsheet in the table shows that E-Jobsheet is more flexible than the printed one (jobsheet for lecture guidance, students and manual books which have size A4 standard) because it is more accessible to students and be used on smartphone, PC, and other gadgets.

\section{CONCLUSION AND FUTURE WORKS}

This paper presents the design and implementation of the analog oscillator virtual lab comprising the topics of Wien Bridge, Colpitts, Hartley and Astable Multivibrator.
TABLE I.

PERFORMANCE TEST FOR VIRTUAL LABS ON VARIOUS PC SPECIFICATIONS

\begin{tabular}{|c|c|c|c|c|c|}
\hline No & OS & Processor & RAM & VGA & Memory \\
\hline 1 & $\begin{array}{l}\text { Windows } 8.1 \\
\text { Pro 64-bit } \\
(6.3, \text { Build } \\
9600)\end{array}$ & $\begin{array}{c}\text { In- } \\
\text { tel(R)core } \text { com }^{(\mathrm{TM})} \\
\text { i3-3110M } \\
\text { CPU }\end{array}$ & $\begin{array}{c}\text { 4096MB } \\
\text { RAM }\end{array}$ & $\begin{array}{c}\text { Intel HD } \\
\text { Grapics } \\
4000\end{array}$ & $12,7 \mathrm{MB}$ \\
\hline 2 & Windows XP & $\begin{array}{l}\text { Intel Core } \\
\text { 2Duo CPU }\end{array}$ & $\begin{array}{l}512 \mathrm{MB} \\
\text { RAM }\end{array}$ & $\begin{array}{l}\text { NVIDIA } \\
\text { GeForce } \\
7050\end{array}$ & $939,3 \mathrm{MB}$ \\
\hline 3 & $\begin{array}{l}\text { Windows } 7 \\
\text { Professional } \\
\text { 32-bit }(6.1, \\
\text { Build } 7601)\end{array}$ & $\begin{array}{c}\text { In- } \\
\text { tel(R)core }{ }^{(\mathrm{TM})} \\
\text { i3-3240M } \\
\text { CPU }\end{array}$ & $\begin{array}{c}\text { 4096MB } \\
\text { RAM }\end{array}$ & $\begin{array}{l}\text { Intel HD } \\
\text { Grapics }\end{array}$ & $24,323 \mathrm{~K}$ \\
\hline 4 & $\begin{array}{l}\text { Windows } 7 \\
\text { Ultimate } 32- \\
\text { bit (build } \\
7600)\end{array}$ & $\begin{array}{c}\text { Intel(R) } \\
\text { Atom N2600 } \\
\text { CPU }\end{array}$ & $\begin{array}{c}\text { 2048MB } \\
\text { RAM }\end{array}$ & $\begin{array}{l}\text { Intel Grap- } \\
\text { ics Media } \\
\text { Accelerator }\end{array}$ & $855 \mathrm{MB}$ \\
\hline 5 & $\begin{array}{l}\text { Windows } 7 \\
\text { Professional } \\
\text { 64-bit }(6.1, \\
\text { Build } 7601) \\
\end{array}$ & $\begin{array}{c}\text { In- } \\
\text { tel(R)core } \\
\text { i3-4150 CPU }\end{array}$ & $\begin{array}{c}\text { 2048MB } \\
\text { RAM }\end{array}$ & $\begin{array}{c}\text { Intel HD } \\
\text { Grapics } \\
4400\end{array}$ & $743 \mathrm{MB}$ \\
\hline 6 & $\begin{array}{l}\text { Windows } 7 \\
\text { Professional } \\
\text { 32-bit }(6.1, \\
\text { Build } 7600) \\
\end{array}$ & $\begin{array}{c}\text { Intel(R) } \\
\text { Pentium Dual } \\
\text { CPU E220 }\end{array}$ & $\begin{array}{c}4096 \mathrm{MB} \\
\text { RAM }\end{array}$ & $\begin{array}{l}\text { NVIDIA } \\
\text { GeForce } \\
7050\end{array}$ & $21,544 \mathrm{~K}$ \\
\hline 7 & $\begin{array}{l}\text { Windows } \\
\text { Vista }\end{array}$ & $\begin{array}{c}\text { Intel Core } \\
\text { 2Duo P8600 }\end{array}$ & $\begin{array}{c}2042 \mathrm{MB} \\
\text { RAM }\end{array}$ & $\begin{array}{l}\text { NVIDIA } \\
\text { GeForce } \\
9600 \mathrm{~m} \mathrm{GT}\end{array}$ & $880 \mathrm{MB}$ \\
\hline 8 & Windows 7 & $\begin{array}{c}\text { AMD } \\
\text { Phenom II } \\
\text { X3 } 720\end{array}$ & $\begin{array}{c}\text { 4096MB } \\
\text { RAM }\end{array}$ & $\begin{array}{l}\text { ATI Radeon } \\
\text { HD } 4850\end{array}$ & $800 \mathrm{MB}$ \\
\hline
\end{tabular}

Another product developed is e-jobsheet which is a supplementary for conducting a practical or an experiment digitally. While the discussion on results of validation tests like those on media, material and langauge by the experts in media so well as responses from students towards this particular virtual lab will be the topic of interest of the upcoming research.

The developed Virtual Laboratory is ready to be uploaded on the website, but it takes up bandwidth that can only be accessed via very fine Internet connection as well as via flash program which is likely to be debugging when operated online on the web. Appropriate interface is also required, which is simple, lightweight, and not debugging, which in this case when using PHP Programming.

For further product development, we will (1) add video tutorial into a virtual lab to further facilitate the practical implementation and provide options for slow music or songs to accompany while using in order to create feelings of comfort and being not easily bored; (2) integrate ejobsheet with a virtual lab into a single learning media package for a more practical use; (3) present the materials in text with animation to add more attractiveness; (4) integrate virtual lab with an evaluation tool that generates at random; (5) add more material of oscillator like Crystal oscillator, Twin-T, Clapps and other types of analog oscillator for more varied virtual lab; (6) make available for Virtual laboratory to be accessed online and bilingual; in English and in Bahasa Indonesia. 
TABLE II.

COMPARATION OF VIRTUAL LAB AND REAL LAB IN PRACTICAL CASES OF ASTABLE MULTIVIBRATOR WITH R=20K $\Omega$ AND C=100NF

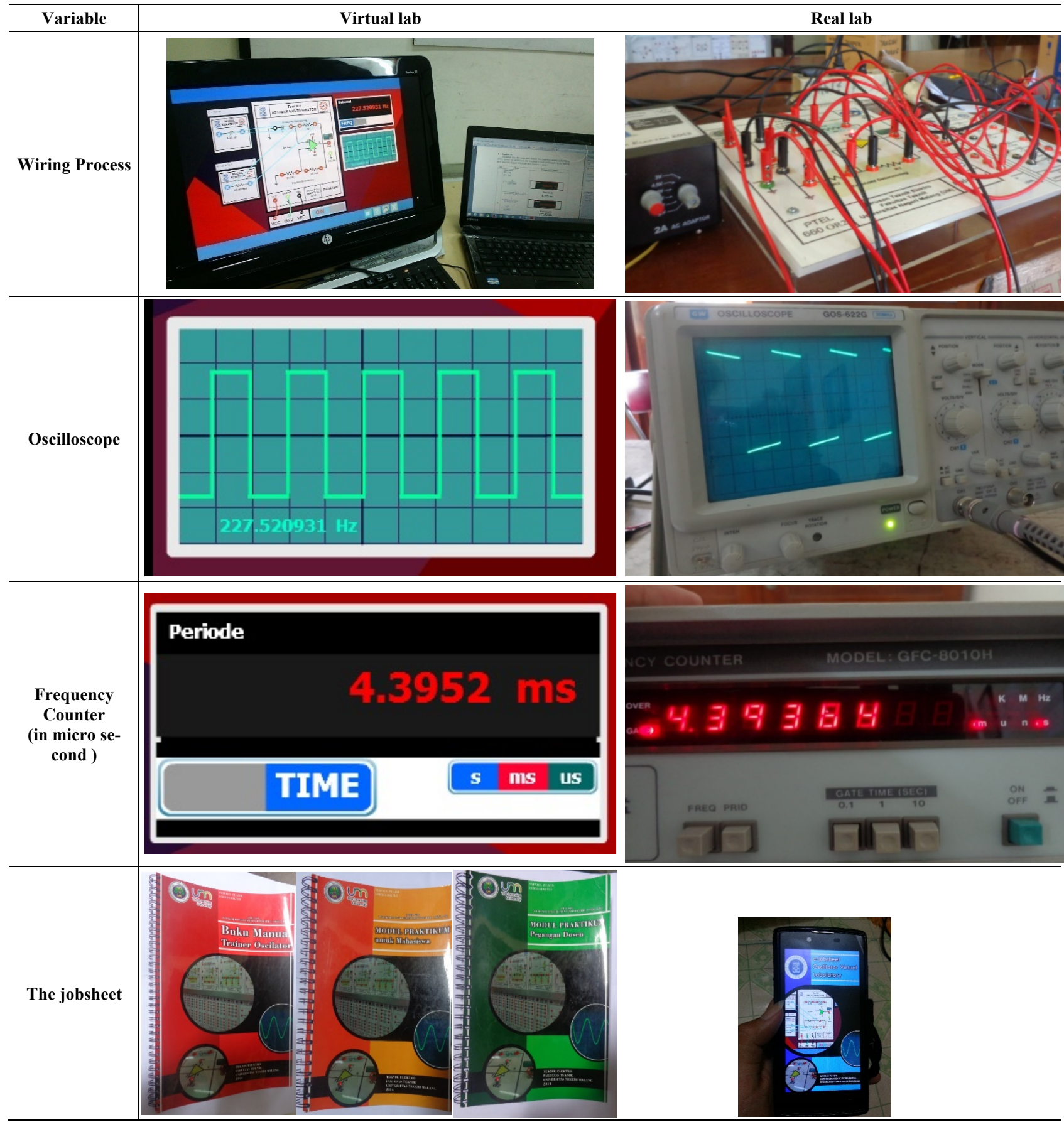

\section{REFERENCES}

[1] M. Budhu, "Virtual Laboratories For Engineering Education," Int. Conf. of Engineering Education, pp. 1-6, Agust 2001.

[2] M.T. Valdez et al., "Virtual Labs in Electrical Engineering Education- The VEMA Project," Information Technology Based Higher Education and Training (ITHET), pp. 1-5, 2014.

[3] Muchlas, "Pengembangan V-Lab Menggunakan Aplikasi Online Meeting dan Simulator Breadboard untuk Praktikum Elektronika Digital,"Proc. of Pertemuan Ilmiah XXVIII HFI, pp. 38-41, April 2014.

[4] P. Abreu et al., "Experiments with a Virtual Lab for Industrial Robots Programming," Int. Journal of Online Engineering (iJOE),
Vol.11(5), pp. 10-16, 2015. http://dx.doi.org/10.3991/ijoe.v11i5. 4752

[5] V. Potkonjak et al., "Virtual Mechatronic/Robotc Laboratory" - A step further in distance learning," Computers and Education, Vol.55, pp. 465-475, February 2010. http://dx.doi.org/10.1016/ j.compedu.2010.02.010

[6] S. Uran, "Virtual Laboratory for Creative Control Design Experiments," Transactions on Education, Vol. 51 (1), pp. 69-75, February 2008. http://dx.doi.org/10.1109/TE.2007.906599

[7] H. Djeghloud et al., "Virtual Labs of Conventional Electric Machines," Int. Conf. on Interactive Mobile and Computer Aided Learning (IMCL), pp. 52-57, November 2012. http://dx.doi.org/10.1109/IMCL.2012.6396450 
[8] N.A Yalcin and F. Vatansever, "A Web-Based Virtual Power Electronics Laboratory," Computer Applications in Engineering Education, Vol. 24(1), pp.71-78, 2015. http://dx.doi.org/10.1002/ cae. 21673

[9] M.D. Redel-Macias et al., "Virtual Laboratory on Biomass for Energy Generation," J. of Cleaner Production, Vol. 112, pp. 38423851, 2016. http://dx.doi.org/10.1016/j.jclepro.2015.07.075

[10] A. Othman et al., "Virtual Lab for Teaching a Computer Programming Course," Int. Conf. on Communication, Media, Technology and Design, pp. 306-312, April 2014.

[11] S. Reimers and N. Steward, "Adobe Flash as a Medium for Online Experimentation: a Test of Reaction Time Measurement Capabilities,"

[12] Behavior Research Methods, Vol. 39 (3), pp. 365-370, 2007. http://dx.doi.org/10.3758/BF03193004

[13] Syifaul F., "Pengujian Trainer Oscilator Wien Bridge dengan Menggunakan Osciloskop dan Frekuensi Counter". Proc. of Seminar Nasional Teknologi Informasi dan Aplikasinya (SENTIA), Vol.6 pp. A32 - A36, June 2014.

[14] S. Fuada et al., "Design and Fabrication of LC-Oscillator Tool Kits Based Op-Amp for Engineering Education Purpose". Vol. 17(1), pp. 88-100, January 2016.

[15] S. Fuada "Pengujian Validitas Alat Peraga Pembangkit Sinyal (Oscillator) untuk Pembelajaran Workshop Instrumentasi Industri," Proc. of Seminar Nasional Pendidikan (SEMNASDIK), pp. 854861, November 2015

[16] S. Fuada, "Pengembangan Trainer Oscilator Pada Mata Kuliah Workshop Instrumentasi Industri (PTEL-660) Di Jurusan Teknik Elektro FT UM," SKRIPSI Jurusan Teknik Elektro Fakultas Teknik UM, 2014

\section{AUTHORS}

Syifaul Fuada is currently pursuing his master's degree in Electrical Engineering at the School of Electrical and Informatic Engineering, Institut Teknologi Bandung (ITB), Indonesia with an option in microelectronics. He was one of the top 106 Indonesian Innovators in 2014, and holds two pending patents entitled, "Solar-based helmet cell charger," and "Out-pipe inspection robot." The author's interest is analog circuitry, smart home applications, embedded systems, digital and analog ICs design, Visible Light Communication (VLC), 2D and 3D graphic design, and journalism. (email: syifaulfuada@pme.itb.ac.id, fsyifaul@gmail.com).

Amy Hamidah Salman was born in Jakarta on May 22, 1956. She received her B.Eng degree in Telecommunication Engineering from the Institut Teknologi Bandung (ITB), Indonesia, in 1980 and her M.Sc (Eng) degree in Electrical, Electronic Engineering from Queen's University, Kingston, Canada in 1990. She is a senior lecturer at ITB and is currently pursuing her doctoral degree in ITB. Her research interests include Electronic and VLSI design. (email: amyhamidah@gmail.com).

This research is supported by Southeast Asian Ministers of Education Organzation (SEAMEO) Regional Open Learning Centre (SEAMOLEC) year 2015 through the Grant for Long Distant Studies (PTJJ) according to the letter of announcemen No. SC.8.29/10696/VI/15. Submitted 03 June 2016. Published as resubmitted by the authors 15 July 2016. 